\title{
Business model innovation in incubators: the role played by dynamic capabilities theory
}

$\underline{\text { Authors }}$

Amandine Maus, U. of Montpellier, amandine.maus@umontpellier.fr

Sylvie Sammut, U. of Montpellier, sylvie.sammut@umontpellier.fr@ 


\title{
Business model innovation in incubators: the role played by dynamic capabilities theory
}

\begin{abstract}
In an increasingly competitive business support industry, incubators are faced with a range of threats. On the one hand, public financiers are reducing the funds allocated and, on the other, entrepreneurs are moving away from "traditional" incubation for more fashionable rival incubation models (such as acceleration, mentoring and coworking for example). In order to better adapt to this turbulence, incubators are bringing about doing business model innovation. To understand how business support structures adapt continuously to their environment, or even to simply get ahead of the competition, we have used the dynamic capabilities theory. A single, longitudinal case study, carried out over a period of 14 months and composed of 34 interviews, revealed that two dynamic capabilities have been created: one to develop the incubation model, and one to integrate partners into the incubator. Thanks to these capabilities, we demonstrate that incubators have triggered a transformation process of business model innovation based on a combination of several business support models. A new generation of incubator business model seems to be emerging, particularly through the development of entrepreneurial behavior in incubators, which are becoming like any other business.
\end{abstract}

\section{Keywords:}

business support, business model innovation, dynamic capabilities, incubator, incubation model 


\section{BUSINESS MODEL INNOVATION IN INCUBATORS: THE ROLE PLAYED BY DYNAMIC CAPABILITIES THEORY}

\section{INTRODUCTION}

In 17 years, the number of incubators ${ }^{1}$ has been multiplied by more than two throughout the world. In the early 2000s, there were 2,000 incubators listed (Economic Commision for Europe, 2001). In 2017, there were 7,000 (van Weele, van Rijnsoever \& Nauta, 2017). This growing number of incubators is partly behind the dynamism found in the business support industry (Baraldi and Ingemansson Havenvid, 2016; Lamine, Mian, Fayolle, Wright, Klofsten \& Etzkowitz, 2016; Mian, Lamine \& Fayolle, 2016; Vanderstraeten and Matthyssens, 2012) and, as a result, increasing competition between business support structures. Incubators are now in competition with new organizations that propose more fashionable incubation models, particularly for the most recent of them (acceleration ${ }^{2}$, coworking ${ }^{3}$, mentoring ${ }^{4}$, etc.) (Baraldi and Ingemansson Havenvid, 2016; Garrett, Spreitzer \& Bacevice, 2017; Lamine et al., 2016; Mian et al., 2016; Pauwels, Clarysse, Wright \& Van Hove, 2016). The latter correspond to the expectations of entrepreneurs who are increasingly moving away from traditional incubation (Fielden and Hunt, 2012). This phenomenon arrives in a context where public resources are on the decline, forcing incubators to search for new sources of funding (Baraldi and Ingemansson

\footnotetext{
${ }^{1}$ According to Hackett and Dilts (2004a), "a business incubator is a shared office space facility that seeks to provide its incubatees (i.e. "portofolio-" or "client-" or "tenant-companies") with a strategic, value-adding intervention system (i.e. business incubation) of monitoring and business assistance" (p. 57).

${ }_{2}^{2}$ Pauwels et al. (2016) define accelerators as "organizations that aim to accelerate successful venture creation by providing specific incubation services, focused on education and mentoring, during an intensive program of limited duration" (p. 13).

${ }^{3}$ Coworking spaces are open space work areas that welcome entrepreneurs. A community of peers is set up there to support them (Garrett et al., 2017).

${ }^{4}$ According to Eeisley and Wang (2017), mentoring is a relationship in which an individual, who is a novice in the entrepreneurial field, is supported by an experienced entrepreneur.
} 
Havenvid, 2016; Pauwels et al., 2016).

This dynamic context has already been highlighted in the literature, notably when studying incubators from the perspective of changes in their strategies (Baraldi and Ingemansson Havenvid, 2016; Pauwels et al., 2016; Bank, Fichter \& Klofsten, 2017). The business model is a privileged concept for understanding the adaptations made by incubators (Bruneel, Ratinho, Clarysse \& Groen, 2012; Pauwels et al., 2016; von Zedtwitz, 2003) and their ability to retain their high performances within their industry. The performances of an organization improve in particular when it does business model innovation, in other words when its business model evolves (Foss and Saebi, 2017; Morris, Schindehutte \& Allen, 2005; Zott, Amit \& Massa, 2011; Zott and Amit, 2007, 2008, 2010). Bruneel et al. (2012) and Pauwels et al. (2016) revealed that several generations of business model for business support structures have succeeded one another. Their value proposition (Demil and Lecocq, 2010; Demil, Lecocq, Ricart \& Zott 2015; Foss and Saebi, 2017) has transformed to respond to the perpetually changing needs of entrepreneurs. Studying incubator business models in the literature nevertheless revealed a gap that we hope to help fill with this article. Previous research effectively did not make it possible to understand how incubators bring about change in their business models (Foss and Saebi, 2017), and more specifically which capabilities allow these organizations to transform them. Our research thus focuses on this gap in the literature, mobilizing in order to do so the dynamic capabilities theory (Pezeshkan, Fainshmidt, Nair, Lance Frazier \& Markowski, 2016; Teece, 2007, 2014; Wu, Chen \& Jiao, 2016; Zott, 2003). Researchers have already underlined the key role played by these dynamic capabilities in transforming the business models of businesses (Achtenhagen, Melin, \& Naldi, 2013; DaSilva and Trkman, 2014; Teece, 2007, 2010, 2014). We thus asked questions concerning the aptitude of incubators to create such capabilities in order to remain efficient, by 
means of the following research question: how incubators do business model innovation to respond to the threats of the business support industry?

A single, longitudinal case study was carried out in depth to answer this question (Eisenhardt, 1991; Eisenhardt and Graebner, 2007; Eisenhardt, Graebner \& Sonenshein, 2016 Myers, 2013). This research method was chosen as it is a pertinent means of exploring a subject that is discussed little in the literature (Eisenhardt and Graebner, 2007): the dynamic capabilities of incubators. It made it possible to answer questions covering "why" and "how", in harmony with our research which focuses on the way in which incubator business models evolve. In addition, a single case study makes it possible to generate greater theoretical richness than a multiple case study, in which the variety of knowledge is reduced by the search for elements common to all cases (Eisenhardt and Graebner, 2007). An incubator was studied for 14 months to understand how it do business model innovation. In total, thirty-four semi-directive qualitative interviews were carried out with a range of the stakeholders involved in the implementation of this business model (manager, employees, supported entrepreneurs, partners). These interviews were completed with secondary data and observations.

The results revealed the existence of two dynamic capabilities: one for developing new incubation models, and one for integrating partners into the organization. They produced significant changes in the incubator's business model. By acting simultaneously, they generated a phenomenon for combining different incubation models within the incubator. Two new models were thus added to its traditional incubation: first coworking, and then acceleration. These transformations had a positive influence on the performances of the incubator. 
The contribution of this research is thus to underline the emergence of a new generation of incubator business model. It is based on the addition of a variety of incubation models: "traditional" incubation, acceleration and coworking for the case studied. This new generation has been created thanks to behaviors for detecting and pursuing opportunities developed by the incubator studied. Our research is thus complementary to existing work in the field of entrepreneurship, highlighting the entrepreneurial behavior of incubators.

This article is structured as follows: we start with a review of the literature. The works that study the business models of incubators and their changes are described in detail. The theoretical framework focusing on dynamic capabilities is also explained. The methodological framework is then described in detail and the case of the incubator studied is presented. Two dynamic capabilities developed by this incubator, as well as the trajectory of its business model, are then outlined. Finally, these results are discussed from the perspective of the literature, and both theoretical and practical contributions are suggested.

\section{THEORETICAL BACKGROUND}

\section{Successive Generations of Incubator Business Models}

In the last decade, a strategic perspective has emerged in the literature on incubators (Bank et al., 2017; Baraldi and Ingemansson Havenvid, 2016; Bruneel et al., 2012; Pauwels et al., 2016 Vanderstraeten and Matthyssens, 2012). It completes the more traditional managerial approach in which incubators are understood as the managers of resources for entrepreneurs (Hackett and Dilts, 2004a; Dutt, Hawn, Vidal, Chatterji, McGahan \& Mitchell, 2016; Somsuk and 
Laosirihongthong, 2014; Van Weele et al., 2017). The strategic approach was developed to better understand the changes in the entrepreneurial business support industry (Baraldi and Ingemansson Havenvid, 2016; Bruneel et al., 2012; Vanderstraeten and Matthyssens, 2012; Pauwels et al., 2016). Incubators used three factors to re-evaluate themselves: (1) competition from the plurality of new incubation models, some of which require payment - accelerators, coworking spaces, etc. (Garrett et al., 2017; Pauwels et al., 2016), (2) new generations of entrepreneurs who are no longer satisfied with traditional forms of incubation (Fielden and Hunt, 2011), and (3) a drop in public subsidies, forcing incubators to search for new financial resources (Baraldi and Ingemansson Havenvid, 2016; Pauwels, et al., 2016).

In order to understand how support structures adapt in this dynamic context, strategic management concepts are used. Incubators can then be considered to be businesses like any other, developing strategies, multiplying, and integrating change into their business models (Baraldi and Ingemansson Havenvid, 2016; Bruneel et al., 2012; Clarysse, Wright, Lockett, Van de Velde \& Vohora., 2005; Vanderstraeten and Matthyssens, 2012; Pauwels et al., 2016; von Zedtwitz, 2003). The concept of business model proposed by Zott and Amit (2010) is used in an original context: that of incubators. The researchers understood this as: "a system of interdependent activities that transcends the focal firm and spans its boundaries. The activity system enables the firm, in concert with its partners, to create value and also to appropriate a share of that value." (Zott and Amit, 2010: 216). The aim of the business model is to exploit opportunities that will modify the organization's resources and activities (Amit and Zott, 2001; George and Block, 2011; Sosna, Trevinyo-Rodriguez \& Ramakrishna, 2010; Zott et al., 2011; Zott and Amitt, 2010;). Thanks to these opportunities, firms do business model innovation, defined as "designed, novel, nontrivial changes to the key elements of a firm's business model and/or the architecture linking these 
elements." (Foss and Saebi, 2017: 201). It enhances the performances of the organization that implements it - in our case, incubators (Dahan, Doh, Oetzel \& Michael., 2010; Demil and Lecocq, 2010; Foss and Saebi, 2017; Morris et al., 2005; Zott et al., 2011; Zott and Amit, 2007, 2010).

Thus, to be more efficient, incubators have continuously modified their business models in relation to the expectations of their entrepreneur clients (Bruneel et al., 2012; Pauwels et al., 2016). The works by Bruneel et al. (2012) present, ex post, three generations of incubator that succeeded one other between 1950 and 1990. These three generations are based on different value propositions, one of the elements that make up the concept of business model (Demil and Lecocq, 2010; Foss and Saebi, 2017). A first generation of incubator, created in the 1950s, was based on the sharing of offices between entrepreneurs; in the 1980s, the value proposition of a second generation of business model was based on individual business support which ensured the follow-up of entrepreneurs over several years (Rice, 2002; Patton, 2014); in 1990, a third generation developed a vast professional network that it offered to entrepreneurs, whilst cumulating it with the previous value propositions. In addition to these first three generations, and according to Pauwels et al. (2016), a new, and thus fourth, generation of business support business model developed in 2005: the business model of accelerators ${ }^{5}$. This business model cohabits in the entrepreneurial support industry with those of incubators. It nevertheless corresponds to the new needs of entrepreneurs, linked to their desire to enter their market more quickly or to come into contact with their peers (Garrett et al., 2017). Since 2005, other business

\footnotetext{
5 The business model of accelerators is based on support that is both individual and collective, proposed for periods that last only a few months (Cohen, 2013; Mian et al., 2016; Pauwels et al., 2016). A contact-making activity is particularly well-developed within a large network composed of businesses and private investors.
} 
models can be noted in the industry, such as that of coworking spaces ${ }^{6}$. To remain efficient, the question of adaptation to this new generation of business model is thus raised for incubators.

\section{Dynamic Capabilities as the Motor for the Incubator Business Model Innovation}

Today, continuing the transformation of their business models is essential for incubators. They thus modify the value created for clients who are less and less satisfied with their support (Bruneel et al., 2012). However, the capacity for adaptation that incubators have, and that make such evolution possible, remain, to date, unknown. To understand them, we used the literature on strategic management and, in particular, dynamic capabilities theory as a means of explaining the business model innovation (Achtenhagen et al., 2013; DaSilva and Trkman, 2014; Teece, 2007, 2010, 2014). This theory is based on the Resource-Based View (RBV) approach (Teece, 2014; Zott, 2003), frequently used to study incubators (Aaboen, 2009; Somsuk and Laosirihongthong, 2014; Vanderstraeten and Matthyssens, 2012; van Weele et al., 2017). We mobilized the dynamic capabilities theory to overcome the static nature of the RBV criticised in the literature (Zott, 2003). It does not make it possible to understand how organizations adapt and remain efficient in changing environments, like that of business support.

We based our research on the definition of dynamic capabilities proposed by Teece (2007). It can easily be operationalized to detect these capabilities. Teece (2007) indicated that dynamic capabilities are capabilities that make it possible "(1) to sense and shape opportunities and threats, (2) to seize opportunities, and (3) to maintain competitiveness through enhancing,

\footnotetext{
${ }^{6}$ The business model of coworking spaces focuses on collective business support (Garrett et al., 2017). It is orchestrated by a community leader who coordinates the exchanges between entrepreneurs.
} 
combining, protecting, and, when necessary, reconfiguring the business enterprise's intangible and tangible assets." (Teece, 2007:1319). To take advantage of the opportunities created or detected, these capabilities transform the business models. They succeed by acting on routines, resources and skills (Arend, 2014; Eisenhardt and Martin, 2000; Teece, 2007, 2014; Zahra, Sapienza \& Davidsson, 2006; Zollo and Winter, 2002; Zott, 2003). They either modify them or create new ones. In other words, Zahra et al. (2006) indicated that dynamic capabilities are "the ability to change the way the firm solves its problems" (Zahra et al., 2006: 921). Dynamic capabilities thus provide new avenues for the adaptation of businesses, and develop their performances (Arend, 2014; Pezeshkan et al., 2016; Teece, 1997, 2007, 2014; Zahra et al., 2006; Zott, 2003). Dynamic capabilities theory is used widely in the study of multinational businesses (Teece et al., 1997, 2014; Wu et al., 2016), as well as in that of SMEs (Achtenhagen et al., 2013; Arend, 2014). It has also been questioned in the literature on incubators. Hackett and Dilts (2004b) studied the input of this theory in the context of support structures. According to these authors, "A dynamic capabilities approach would facilitate inquiries into the way in which an incubator, over time, builds new venture development resources and capabilities, and allocates these resources to the transformation of incubatees into value-producers." (Hackett et Dilts, 2004b: 46). But back in 2004, Hackett and Dilts did not use it because of the lack of competition between incubators. Thirteen years later, things have changed: the business support industry is now competitive (Baraldi and Ingemansson Havenvid, 2016; Mian et al., 2016; Vanderstraeten and Matthyssens, 2012). It thus appeared relevant to us to explore the dynamic capabilities of incubators.

These capabilities are behind a process of evolution in routines and the business models of organizations (Achtenhagen et al., 2013; DaSilva and Trkman, 2014 Teece, 2007, 2010, 2014). 
We hoped to identify this process within incubators. From this point of view, our qualitative study will allow us to identify two elements:

(1) The business model of the incubator studied and its evolutions: we based our work on the definition developed by Zott and Amitt (2010) to understand it, that is, the content of the activities implemented, their architecture (how the activities are articulated between each other) and their governance (the actors that perform them) (Zott and Amitt, 2010: 220).

(2) The dynamic capabilities of the incubator: we identified them thanks to the entrepreneurial process that they generate. The first phase of the process occurs in interaction with the environment (creating or detecting, and pursuing opportunities). The second phase then occurs within the organization (transforming routines, resources and skills) (Arend, 2014; Eisenhardt and Martin, 2000; Teece, 2007, 2014; Zahra et al., 2006; Zollo and Winter, 2002; Zott, 2003).

\section{METHODOLOGY}

\section{A Single, Longitudinal Case Study}

The incubator studied is located in France. It was founded in 1988 by a consular chamber in the form of an association. This structure enjoys now a certain reputation in the field of innovation in the local area. It supports the creation of innovative businesses up to two years before their creation and up to five year after. On July $1^{\text {st }}, 2017,17$ business owners and 12 project initiators were supported by a team composed of 5 people: a manager, two coaches and two assistants.

This case was selected for two reasons. (1) On the one hand, its date of creation (1988) shows that it is one of the pioneering incubators in France. The support actors effectively developed 
during the 1980s (Messeghem, Carrier, Sammut, Thurik, \& Chabaud, 2013). It is interesting to note that its seniority has allowed it to see the new arrivals take up position in the entrepreneurial support industry in the last decade and transform it. The incubator's team has been able to take inspiration from this to change its practices. (2) On the other, it has the characteristics of a third generation incubator as evoked by Bruneel et al. (2012); that is, its activity of establishing contacts is well-developed with a wide range of partners. This generation appeared in 1990. We can thus suppose that the incubator has known how to adapt over time in order to respond to the expectations of entrepreneurs by belonging to the different generations that have developed in succession. The presence of dynamic capabilities within it could thus be envisaged.

In this research, we focused on two projects developed successively in the incubator (Figure 1): the creation of a coworking space and an accelerator. Both these projects made it possible to respond to several ambitions: (1) reinforcing the attractiveness of the incubator and its region, in order to attract entrepreneurs and financiers; and (2) bringing about change in the support profession, brought into doubt by the arrival of new actors: business accelerators in particular.

\section{Insert Figure 1 about here}

\section{Collecting and Analyzing the Data from the Case}

We chose a single case, studied in a longitudinal and indepth manner (Eisenhardt, 1991; Eisenhardt et al., 2016; Eisenhardt and Graebner, 2007; Miles and Huberman, 1994; Myers, 2013; Yin, 2013). The longitudinal nature of this research allowed us to capture the reality of the 
incubator at a given instant, as well as the richness of the context in which it is anchored (Myers, 2013). The aim of the case study is not to generalize the results: it external validity is weak. It objective is to create new knowledge that could possiblely lead to developing a new theory (Eisenhardt et al., 2016; Eisenhardt and Graebner, 2007; Yin, 2013). The case study method makes it possible to respond to questions concerning the "how" or "why" in as-yet unexplored areas of research (Eisenhardt and Graebner, 2007; Yin, 2013). Our study effectively focused on understanding the evolution process for the business model of incubators ("how") and the dynamic capabilities that influence it ("why"). The advantage of our choice of a single case lies in the exploratory aspect of this research (Eisenhardt and Graebner, 2007; Miles and Huberman, 1994; Myers, 2013). The single case has the virture of providing a greater variety of knowledge than multiple cases. The search for elements common to all cases results in a reduction in the richness of the knowledge created. To explore the as-yet unknown dynamic capabilities of incubators, the input of varied and original knowledge thanks to a single case study was sufficient initially. It could be completed by a study of multiple cases in a second phase.

This research was carried out in an original manner. Although an evolution process for incubator business models has been highlighted by certain researchers (Bruneel et al., 2012; Pauwels et al., 2016), it has not been understood at an empirical level in a longitudinal format. This method thus provides additional proof that there is evolution in incubators over time. In addition, the multiactor approach chosen (manager, employees of the incubator, supported entrepreneurs, coaches) made it possible to perceive the business model studied from different points of view (Bruneel et al., 2012) and avoid the bias associated with the perception of the business model by the manager of the incubator alone (Bruneel et al., 2012). 
In order to monitor the process of business model innovation within the incubator studied, the research design developed was based on four immersions carried out in 2016 and 2017 within the same organization (Table 1).

\section{Insert Table 1 about here}

During these immersions, semi-directive interviews (Myers, 2013) were carried out with third parties selected for their involvement in the implementation of the business model. The members of the incubator's team (manager, coaches, assistants), the supported entrepreneurs and the support partners (consultant, support structure) were interviewed. Interview guides adapted to the actors and the immersion periods were used. Thirty-four semi-directive interviews lasting between 20 and 80 minutes were carried out. All were recorded and transcribed. Observations were also made during each immersion (during team meetings and support meetings), and secondary data were collected with the aim of triangulating the information obtained (Yin, 2013; Eisenhardt et al., 2016). The data source triangulation allowes to increase the internal validity of this indepth case study.

A data analysis process was conducted in two phases. The first phase was based on open, themed coding (Miles and Huberman, 1994). It was carried out separately for each immersion period. The codes obtained from the literature were defined and mobilized, whilst leaving room for the emergence of codes from the data. The predefined codes concerned: the elements of the business model, the creation process and the mobilization of dynamic capabilities, as well as the support models. During this phase, all the interviews were coded per type of actor interviewed (manager, 
coach, assistant, entrepreneur, partner). The observations were then coded separately, as were the secondary data. The software Nvivo10 was used to perform this task. The second phase of the study was carried out from the construction of chronological matrices for each study period (Miles and Huberman, 1994) (Appendix A). The data from the matrices come from coding done previously. A comparison between immersion periods was made possible by analyzing the matrices.

\section{FINDINGS}

Our case study revealed that evolution in the business model of the incubator studied was based on two dynamic capabilities. Combining them generated an integration phenomenon of the different incubator models within the incubator. To shed light on these results, we will initially give details of the business model of the incubator identified during our first immersion (April 2016); secondly, we will analyze the two evolution processes for the business model triggered by the dynamic capabilities (Figure 2).

\section{Insert Table 2 about here}

\section{Traditional Incubation as the Basis for the Business Model}

At the start of this research, the business model of the organization studied was based on the incubation of supported businesses. This business model focused on different activities, and in particular three key activities: 
(1) A core business activity: supporting entrepreneurs in an individual format, also known as traditional incubation. Personalized follow-up was proposed by two salaried coaches and by the manager. Thanks to the coaches, the entrepreneur is brought into contact with various professionals. With this objective, partnerships have been developed with actors in the public sector. Service providers from the private sector have also been selected, as shown with partner 1, the manager of an internet platform that brings entrepreneurs into contact with consultants: "[The incubator's coaches] took consultation credit with us. [...] Then, they started to work on training programs with [incubator X]. And I had already been working with [incubator X] for a little while, particularly regarding training. As a result, for their common training programs, I have organized courses” (Partner 1, June 2016).

(2) This incubation program is based on an entrepreneur selection activity. This activity is carried out by the coaches and the manager. Several criteria are used, including one major one: the degree of innovation of the entrepreneurial project. The incubator specializes in supporting innovative businesses. This strategic choice allows the team to have privileged access to public funds specifically destined for innovative entrepreneurs.

(3) Public funding also makes up the financial structure of the incubator. The manager, supported by his assistants, makes efforts to maintain it, year after year, despite proven budget reductions: "Last year, we were in the red because it depended on cuts in 2014 and 2015: there were a lot of subsidy cuts" (Assistant 1, September 2016). A funding research activity, carried out by the members of the incubator team, is essential for the incubator's operations. 
The activities of this business model have been transformed by the combined actions of two dynamic capabilities: one capacity to develop support models, and another to include partners in the incubator. These generate an integration phenomenon for the support models: incubation, coworking and acceleration (Appendix A and B).

\section{A Combination of New Incubation Models}

The first stage in the evolution of the business model: adding a coworking space

(1) The detection and pursue of the opportunity to create a coworking space

The manager of the incubator developed an innovative business model thanks to an opportunity that had been detected: creating a coworking space within his incubator. This approach was particularly original: no other structure in the region of the incubator was proposing to combine this new form of incubation model with traditional incubation. The manager made use of his second dynamic capability: that of integrating partners into the incubator as a means of delegating part of this project. He hired a third party, Assistant 3, who had organization strategy skills. Together, they worked on strategic issues: the outcome of incubation within a coworking space was questioned by hosting a community.

(2) Evolution in routines, resources and skills by means of dynamic capabilities

The coworking space opened in late 2016. Its creation triggered modifications in the incubator's routines. To gauge the relevance of implementing a coworking space and hosting, monthly reflections were held by the team with regard to the performances of the structure: "Every month, I am supposed to present the indicators [of the incubator's performances] to the rest of the team at 
the first service meeting" (Coach 1, September 2016). The aim is to improve the support offered to entrepreneurs. A constant search for private funding was associated with this approach for measuring performances, borrowed from management in the private sector. The vision developed by the incubator's employees for the coworking space is to generate turnover. This search is continuing through the development of other incubation models in the same vein as coworking. After product innovation (provided by coworking), process innovation has been created. The members of the team develop skills in the management of the coworking space, which allows them to invoice the entrepreneurs for services.

(3) Transformation of the business model thanks to the coworking space

This skill was represented by the development of a new activity which modified the incubator's business model: "We're moving more and more into services for businesses, I can feel it" (Manager, January 2017). This is typically associated with coworking. In the context of this activity, the assistants and manager make new material resources available to entrepreneurs. The offices in the coworking space are offered to new clients in return for paid rent: entrepreneurs not receiving support. This activity is completed by reinforcement of the hosting activity of the already existing community. The members of the team coordinate the intervention of external third parties for the entrepreneurs hosted. A wide range of events is thus organized within the coworking space.

Evolution in the business model generated by the two dynamic capabilities has led to a phenomenon of integration of the support models. Associated with the original incubation, there are now activities of services for businesses and network hosting. These activities are typical of coworking. This type of integration is a source of increased performances for the incubator. 
Effectively, by considerably increasing the number of projects supported (multiplied by 1.6 for the period between April 2016 and June 2017) and thus generating turnover, the members of the incubator can increase their visibility on the market, and thus make investments in terms of capabilities and skills. In addition to the positive influence of the coworking space on the business model, the creation of an accelerator has further multiplied the effects.

The second stage in the evolution of the business model: creating a business accelerator

(1) The detection and pursue of the opportunity to create a business accelerator

At the end of 2016, the manager continued the transformation of the incubator's business model. He was aiming to innovate by creating a business accelerator, particularly because no other such structure was present in his region at that time. This opportunity sprang from a meeting with an executive from a large company. The capacity for developing support models was mobilized. To develop a business accelerator, one key resource was nevertheless missing from the incubator: a network in the private sector. The ability to integrate partners into the incubator was used to fill this need: this project was developed in partnership with the large company. It will open at the end of 2017 or the start of 2018.

(2) Evolution in routines, resources and skills by means of dynamic capabilities

To develop this project, the dynamic capabilities created new routines based on the search for private partners. On the one hand, this search was made in the individual support activity, in which the coaches needed external participants to respond to the needs of the entrepreneurs, and, on the other, in the activities for developing the incubator. For example, the manager included a new partner in a program carried out with other incubators to reduce their costs. The accelerator 
project was part of this continuity. The network development skill, already present in the incubator, was reinforced. Another skill developed: the creation of acceleration programs. It was linked to a routine for the continuous improvement of the professions in the incubator and was developed by means of dynamic capabilities: "We wanted things to change and move forwards in our profession" (Assistant 2, September 2016).

(3) Transformation of the business model thanks to the business accelerator

The activity for designing acceleration programs, created by the accelerator project, was carried out by the manager of the incubator: "As part of this program, I am responsible for putting together the acceleration program" (Manager, May 2017). He also coordinates the activity for developing a network, which is thus reinforced. In the context of putting together the acceleration program and the premises of the accelerator, the manager of the incubator made available his skills and necessary experience for the employees of the large company (support skills etc.). In return, the latter provided funds of private origin. The incubator's business model once again generated private financing.

Both of the activities developed in the incubator's business model (development of acceleration programs and the development of a network) played a part in integrating incubation, coworking and acceleration into the whole. These skills are effectively characteristic of accelerators. They reinforce the performances of the incubator. The activity of developing a network thus made it possible:

- On the one hand, to bring the entrepreneurs into contact with the partner large company with the aim of encouraging their growth: "And B. [the manager of the incubator] quite often thinks of us for industrial issues because we are most likely the only start-up in the 
industrial sector [in the incubator]. As soon as there's an industrial issue, or recycling, he thinks of us. In particular, he set up meetings for us with the people from [the partner large company]" (Entrepreneur 3, January 2017);

- On the other, to generate the new financial resources essential for the acceleration project.

\section{DISCUSSION AND CONCLUSION}

The present research focuses on understanding how the incubators do business model innovation, and the capabilities behind this process. This paper makes it possible to put forward several theoretical contributions.

Our first contribution highlights the existence of a new phenomenon in the entrepreneurial support industry: the combination of incubation models. This phenomenon may be the origin of the emergence of a new generation of incubators. Until now, the literature has focused on the distinction between the different incubation models. Traditional incubation (Aernoudt, 2004; Bergek and Norrman, 2008; Bruneel et al., 2012; Hackett and Dilts, 2004a) has, for example, been presented as different from, and incompatible with, acceleration (Cohen, 2013; Lamine et al., 2016; Mian et al., 2016; Pauwels et al., 2016) or coworking (Garrett et al., 2017). This research shows that this distinction is no longer clear-cut in the entrepreneurial support industry. Our single, longitudinal case revealed that the control incubator tended to integrate different support models into a single structure. This new generation of business mdoel is the fifth (Bruneel et al., 2012; Pauwels et al., 2016). It plays a part in continuing the works carried out by Bruneel et al. (2012) and Pauwels et al. (2016). It shows the desire incubators have to adapt in an environment that has become turbulent, and in which both competition is growing and funding from the public 
sector is becoming scarce. To maintain performance levels and attract new financial resources, it is no longer envisageable to continue with the classic form of incubation that entrepreneurs are turning away from. The incubator studied thus added to its business model the support models that are currently more appealing to entrepreneurs or public authorities. These include in particular acceleration and coworking. Our research also shows that the joint development of these two dynamic capabilities is behind this business model innovation.

The second theoretical contribution of this paper lies in the mobilization of dynamic capabilities to study incubators business model innovation. In using the works by Zott (2003), Zahra (2006) and Teece $(2007,2014)$, we have highlighted two dynamic capabilities: that of developing support models and that of including new partners in the incubator. Both these dynamic capabilities make it possible to (1) create or detect opportunities, (2) take up these opportunities, and (3) transform the routines, resources and skills of the incubator (Teece, 2007, 2014; Zahra, 2006; Zott, 2003; Wu et al., 2016). They act in an interdependent manner to bring about profound transformations to the business model. Thanks to this research, we confirm the works from the past which presented dynamic capabilities as a driving force behind the evolution in business models (Achtenhagen et al., 2013; DaSilva and Trkman, 2014; Teece, 2007, 2010, 2014). We have extended this research by using dynamic capabilities theory to study the transformations of incubators. To our knowledge, dynamic capabilities have never been studied within this very specific environment. The aim of the dynamic capabilities of incubators is to provide original solutions (combining new incubation models) in an entrepreneurial support industry that is becoming increasingly dynamic as a result of (1) increased competition between organizations, (2) the new needs of entrepreneurs, and (3) the scarcity of public funding. The integration of 
dynamic capabilities by the manager of the incubator allowed him to develop entrepreneurial strategies, like the manager of any other type of business.

The third contribution of this paper is thus to show that incubators have become businesses like any other. In order to face up to a dynamic context in which competition is fierce (Baraldi and Ingemansson Havenvid, 2016; Vanderstraeten and Matthyssens, 2012), financial resources are becoming thin on the ground (Messeghem et al., 2013) and the entrepreneur clients are turning away from traditional incubation (Fielden and Hunt, 2011), incubators are on the watch for new opportunities. Their managers create or detect, then take advantage of opportunities just as the entrepreneurs they support do. These opportunities become reality by adopting new practices for entrepreneurial support or the search for new financial resources. This entrepreneurial comportment may allow them to develop business models with greater performances.

Our research also proposes practical contributions. We advise the managers of incubators to use tools based on the business model to support their evolution, as indicated by both Zott and Amit (2010) and Demil and Lecocq (2010) for the intention of the managers of businesses. In an increasingly dynamic and aggressive entrepreneurial support environment (Baraldi and Ingemansson Havenvid, 2016; Mian et al., 2016; Vanderstraeten and Matthyssens, 2012), devising innovative business models (Foss and Saebi, 2016), like those of other businesses, seems essential for incubators. This innovation suggests that the managers should mobilize a wide range of partners in order to acquire new resources and skills. These skills support the permanent search for, and creation of, opportunities that may correspond to the conception of new support practices. The public financiers of these incubators will be able to participate in this reflection for the construction of the local economic development tools of the future. They will 
also be able to give the managers of incubators greater autonomy, thus making easier the implementation of entrepreneurial behaviors.

This research nevertheless has certain limitations, providing possible perspectives for future academic work. The first is based on the case study method chosen. Here, we propose a single, longitudinal case study. Our ambition is to develop a study of multiple cases in order to observe the variety in existing dynamic capabilities within incubators. A study of multiple cases, composed of five incubators, is in progress but is not yet complete. The incubator studied for this paper is included. At present, our multiple case study confirms the presence of this new, fifth, generation of incubator.

In addition, in order to generalize the results obtained, and to show the large scale development of the organizations that make up this new generation of incubators presented, a quantitative study could be carried out.

Finally, an international perspective could be another possible extension as our research focused on the case of a French incubator. The evolutions that the support industry has undergone are now effectively global. As indicated in the works of Pauwels et al. (2016) and Mian et al. (2016), the acceleration business model has developed in many countries. It could thus be interesting to compare the evolution in the business models of incubators from different countries, whilst taking into account the specificities of the local entrepreneurial support industry. 


\section{FIGURE 1}

\section{Chronology of events in the incubator studied and the design of the research}

\section{Chronology of the design of the research}

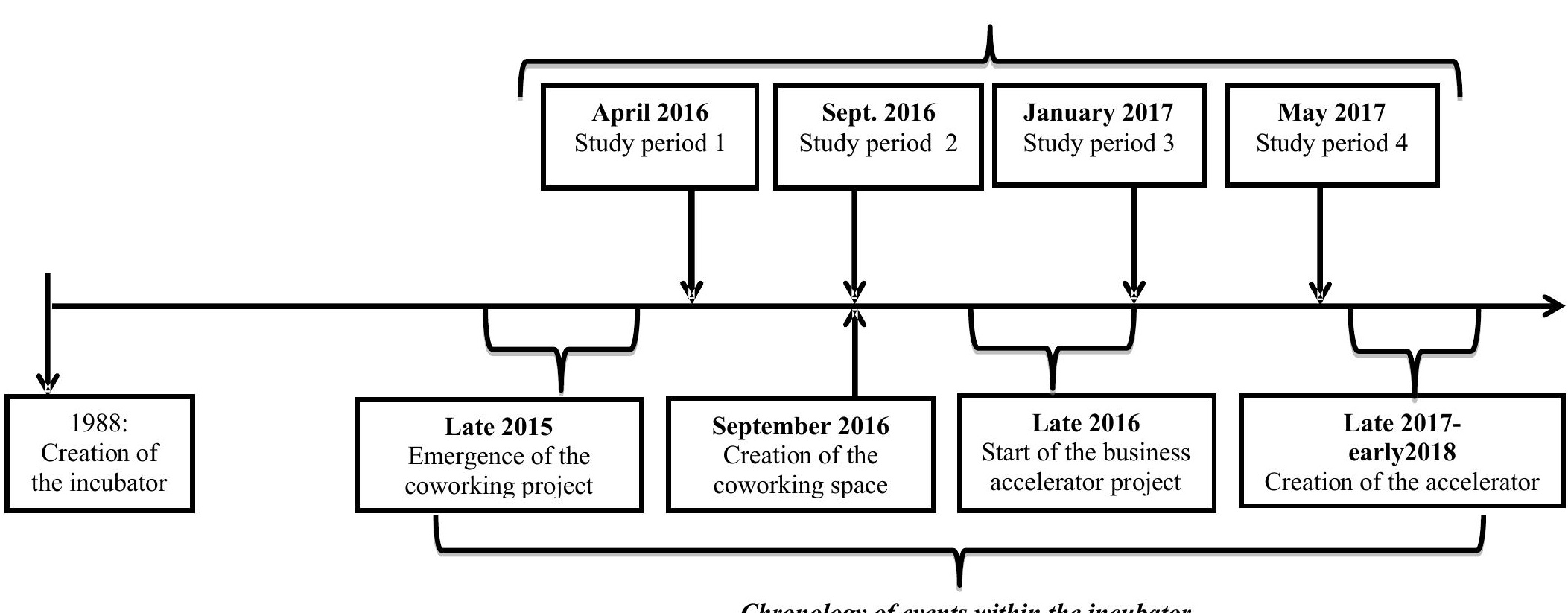

Chronology of events within the incubator 


\section{TABLE 1}

Details of the data collected during the immersions within the incubator

\begin{tabular}{|c|c|c|c|}
\hline $\begin{array}{c}\text { Study period } 1 \\
\text { April } 25 \text { to } 29,2016\end{array}$ & $\begin{array}{c}\text { Study period } 2 \\
\text { September } 5 \text { to } 9 \\
2016\end{array}$ & $\begin{array}{c}\text { Study period 3 } \\
\text { January } 16 \text { to } 19, \\
2017\end{array}$ & $\begin{array}{c}\text { Study period } 4 \\
\text { May } 19 \text { to } 24,2017\end{array}$ \\
\hline $\begin{aligned} & \text { People interviewed: } \\
& \text { - } \text { Manager } \\
& \text { - } \text { Coach 1 } \\
& \text { - } \text { Coach 2 } \\
& \text { - } \text { Assistant 1 } \\
& \text { - } \text { Assistant 3 } \\
& \text { - } \text { Entrepreneur 1 } \\
& \text { - } \text { Entrepreneur 2 } \\
& \text { - } \text { Entrepreneur 3 } \\
& \text { - } \text { Partner 1 }\end{aligned}$ & $\begin{aligned} & \text { People interviewed: } \\
& \text { - } \text { Manager } \\
& \text { - } \text { Coach 1 } \\
& \text { - } \text { Coach 2 } \\
& \text { - } \text { Assistant 1 } \\
& \text { - } \text { Assistant 2 } \\
& \text { - } \text { Entrepreneur 1 } \\
& \text { - } \text { Entrepreneur 2 } \\
& \text { - } \text { Entrepreneur } 3 \\
& \text { - } \text { Partner 2 }\end{aligned}$ & $\begin{aligned} & \text { People interviewed: } \\
& \text { - } \text { Manager } \\
& \text { - } \text { Coach 1 } \\
& \text { - } \text { Assistant 1 } \\
& \text { - } \text { Assistant 2 } \\
& \text { - } \text { Entrepreneur 1 } \\
& \text { - } \text { Entrepreneur 3 } \\
& \text { - } \text { Entrepreneur } 4 \\
& \text { - } \text { Partner 3 }\end{aligned}$ & $\begin{array}{cl}\text { People interviewed: } \\
\text { - } & \text { Manager } \\
\text { - } & \text { Coach 1 } \\
\text { - } & \text { Assistant 1 } \\
\text { - } & \text { Assistant 2 } \\
\text { - } & \text { Entrepreneur 1 } \\
\text { - } & \text { Entrepreneur } 3 \\
\text { - } & \text { Entrepreneur } 4 \\
\text { - } & \text { Partner 4 }\end{array}$ \\
\hline $\begin{array}{c}\text { Number of hours of } \\
\text { observation: } 36 \mathrm{~h}\end{array}$ & $\begin{array}{c}\text { Number of hours of } \\
\text { observation: } 36 \mathrm{~h}\end{array}$ & $\begin{array}{c}\text { Number of hours of } \\
\text { observation: } 36 \mathrm{~h}\end{array}$ & $\begin{array}{c}\text { Number of hours of } \\
\text { observation: } 36 \mathrm{~h}\end{array}$ \\
\hline $\begin{array}{l}\text { Documents collected: } \\
\text { - Activity reports from } \\
\text { 2008, 2009, 2010, } \\
2011,2012,2013 \text {, } \\
2014 \text {; } \\
\text { - Articles written by } \\
\text { the incubator team; } \\
\text { - Communications } \\
\text { published on the } \\
\text { internet. }\end{array}$ & $\begin{array}{l}\text { Documents collected: } \\
\text { - Articles written by } \\
\text { the incubator team; } \\
\text { - Communications } \\
\text { published on the } \\
\text { internet. }\end{array}$ & $\begin{array}{l}\text { Documents collected: } \\
\text { - Articles written by } \\
\text { the incubator team; } \\
\text { - Communications } \\
\text { published on the } \\
\text { internet. }\end{array}$ & $\begin{array}{l}\text { Documents collected: } \\
\text { - Articles written by } \\
\text { the incubator team; } \\
\text { - Communications } \\
\text { published on the } \\
\text { internet. }\end{array}$ \\
\hline
\end{tabular}


TABLE 2

The stages in the innovation business model in the incubator studied

\begin{tabular}{|c|c|c|c|}
\hline & $\begin{array}{l}\text { Initial business model } \\
\text { (April 2016) }\end{array}$ & $\begin{array}{l}\text { Integrated incubation- } \\
\text { coworking business } \\
\text { model (January 2017) }\end{array}$ & $\begin{array}{l}\text { Integrated incubation- } \\
\text { coworking-acceleration } \\
\text { business model (June } \\
2017 \text { ) }\end{array}$ \\
\hline $\begin{array}{c}\text { Content of the } \\
\text { activities }\end{array}$ & $\begin{array}{l}\text { (1) Individual support } \\
\text { (traditional } \\
\text { incubation) } \\
\text { (2) Selecting } \\
\text { entrepreneurs } \\
\text { (3) Searching for funds } \\
\text { (4) Communication } \\
\text { activity } \\
\text { (5) Administrative } \\
\text { activities }\end{array}$ & $\begin{array}{c}\text { New activity: } \\
\text { Management of spaces; } \\
\text { Reinforcement of the } \\
\text { activity: } \\
\text { network hosting } \\
\text { (activity presented } \\
\text { within individual } \\
\text { support) }\end{array}$ & $\begin{array}{c}\text { New activity: } \\
\text { Design of acceleration } \\
\text { programs, } \\
\text { Reinforcement of the } \\
\text { activity: } \\
\text { development of } \\
\text { networks (activity } \\
\text { presented within } \\
\text { individual support) }\end{array}$ \\
\hline $\begin{array}{l}\text { Structure of } \\
\text { the activities }\end{array}$ & $\begin{array}{l}\text { (1) Core business } \\
\text { activity: individual } \\
\text { support (incubation) } \\
\text { (2) Support activities: } \\
\text { the other activities }\end{array}$ & $\begin{array}{c}\text { Peripheral activity: } \\
\text { Managing the } \\
\text { coworking space }\end{array}$ & $\begin{array}{c}\text { Peripheral activities: } \\
\text { Design of acceleration } \\
\text { programs, development } \\
\text { of networks }\end{array}$ \\
\hline $\begin{array}{c}\text { Governance of } \\
\text { the activities }\end{array}$ & $\begin{array}{l}\text { (1) Incubator } \\
\text { employees } \\
\text { (2) Public partners } \\
\text { (3) Private service } \\
\text { providers }\end{array}$ & $\begin{array}{l}\text { The management of the } \\
\text { coworking space } \\
\text { activity was performed } \\
\text { by the employees of the } \\
\text { incubator }\end{array}$ & $\begin{array}{c}\text { The design of } \\
\text { acceleration program } \\
\text { activity and network } \\
\text { development were } \\
\text { performed by the } \\
\text { manager }\end{array}$ \\
\hline
\end{tabular}




\section{APPENDIX A}

TABLE A1

Chronological matrix of the process for constructing and mobilizing dynamic capabilities

\begin{tabular}{|c|c|c|c|c|}
\hline $\begin{array}{l}\text { Stages in the } \\
\text { process for } \\
\text { creating and } \\
\text { mobilizing } \\
\text { dynamic } \\
\text { capabilities }\end{array}$ & Study period 1 & Study period 2 & Study period 3 & Study period 4 \\
\hline $\begin{array}{l}\text { Detecting or } \\
\text { creating } \\
\text { opportunities }\end{array}$ & $\begin{array}{l}\text { Discovery of a } \\
\text { support model in } \\
\text { the region of the } \\
\text { incubator: } \\
\text { coworking. }\end{array}$ & & $\begin{array}{l}\text { While talking } \\
\text { with an } \\
\text { executive from } \\
\text { a large } \\
\text { company, the } \\
\text { manager } \\
\text { perceived an } \\
\text { opportunity to } \\
\text { develop a } \\
\text { business } \\
\text { accelerator in } \\
\text { his region. }\end{array}$ & \\
\hline $\begin{array}{l}\text { Taking up } \\
\text { opportunities }\end{array}$ & $\begin{array}{l}\text { (1) Installing a } \\
\text { coworking space } \\
\text { on the first floor of } \\
\text { the incubator in } \\
\text { the premises into } \\
\text { which the team } \\
\text { was set to move; } \\
\text { (2) Developing } \\
\text { new entrepreneur } \\
\text { clientele that did } \\
\text { not receive } \\
\text { support and who } \\
\text { would pay to be } \\
\text { hosted; } \\
\text { (3) Re-imagining } \\
\text { entrepreneurial } \\
\text { support for } \\
\text { entrepreneurs with } \\
\text { the assistant. }\end{array}$ & & & $\begin{array}{l}\text { (1) Developing } \\
\text { a support } \\
\text { program in } \\
\text { partnership } \\
\text { with a large } \\
\text { company; } \\
\text { (2) Extending } \\
\text { the incubator's } \\
\text { network into } \\
\text { the private } \\
\text { sector. }\end{array}$ \\
\hline
\end{tabular}




\begin{tabular}{|c|c|c|c|c|}
\hline $\begin{array}{l}\text { Transforming } \\
\text { resources }\end{array}$ & & $\begin{array}{l}\text { Setting up a } \\
\text { coworking space on } \\
\text { the first floor of the } \\
\text { incubator and } \\
\text { offices for the } \\
\text { incubator team. }\end{array}$ & $\begin{array}{l}\text { Opening of a } \\
\text { coworking } \\
\text { space and } \\
\text { availability of } \\
\text { physical } \\
\text { resources for } \\
\text { entrepreneurs } \\
\text { (offices, } \\
\text { meeting rooms, } \\
\text { showers, } \\
\text { videoprojector). }\end{array}$ & $\begin{array}{l}\text { (1) Envisaging } \\
\text { creation of a } \\
\text { site for the } \\
\text { accelerator and } \\
\text { scheduled } \\
\text { hiring of a } \\
\text { coach for the } \\
\text { acceleration } \\
\text { program; } \\
\text { (2) Developing } \\
\text { a network of } \\
\text { partners in the } \\
\text { private sector. }\end{array}$ \\
\hline $\begin{array}{l}\text { Creating new } \\
\text { skills }\end{array}$ & & & $\begin{array}{l}\text { (1) Reinforcing } \\
\text { hosting skills; } \\
\text { (2) Creating } \\
\text { skills in the } \\
\text { management of } \\
\text { a coworking } \\
\text { space. }\end{array}$ & $\begin{array}{l}\text { (1) Developing } \\
\text { the skill of } \\
\text { designing the } \\
\text { acceleration } \\
\text { program; } \\
\text { (2) Reinforcing } \\
\text { the network } \\
\text { development } \\
\text { skill. }\end{array}$ \\
\hline $\begin{array}{l}\text { Evolution in the } \\
\text { incubator's } \\
\text { business model }\end{array}$ & & & $\begin{array}{l}\text { Creating a } \\
\text { services for } \\
\text { businesses } \\
\text { activity; } \\
\text { Reinforcing the } \\
\text { hosting } \\
\text { activity. }\end{array}$ & $\begin{array}{l}\text { Creating an } \\
\text { activity for } \\
\text { developing } \\
\text { acceleration } \\
\text { programs; } \\
\text { Reinforcing the } \\
\text { activity for } \\
\text { developing a } \\
\text { network in the } \\
\text { private sector. }\end{array}$ \\
\hline $\begin{array}{l}\text { Controlling } \\
\text { performances }\end{array}$ & $\begin{array}{l}5 \text { project initiators } \\
\text { and } 20 \text { to } 25 \\
\text { businesses } \\
\text { supported by the } \\
\text { incubator }\end{array}$ & $\begin{array}{l}6 \text { project initiators } \\
\text { and } 20 \text { businesses } \\
\text { supported by the } \\
\text { incubator }\end{array}$ & $\begin{array}{l}\text { (1) } 11 \text { project } \\
\text { initiators and } \\
19 \text { businesses } \\
\text { supported by } \\
\text { the incubator; } \\
\text { (2) Two } \\
\text { business } \\
\text { managers } \\
\text { hosted, without } \\
\text { receiving } \\
\text { support, and } \\
\text { who paid for } \\
\text { their } \\
\text { workstation. } \\
\end{array}$ & $\begin{array}{l}\text { (1) Growth in } \\
\text { the number of } \\
\text { entrepreneurs } \\
\text { hosted without } \\
\text { receiving } \\
\text { support and } \\
\text { paying for a } \\
\text { workstation: } 4 \\
\text { entrepreneurs } \\
\text { in May 2017; } \\
\text { (2) Increase in } \\
\text { the number of } \\
\text { project } \\
\text { inititators }\end{array}$ \\
\hline
\end{tabular}




\begin{tabular}{|l|l|l|}
$\mid$ & $\mid \begin{array}{l}\text { receiving } \\
\text { support: 13 } \\
\text { entrepreneurs } \\
\text { and 19 } \\
\text { businesses in } \\
\text { May 2017; } \\
\text { (3) One } \\
\text { entrepreneur } \\
\text { put in touch } \\
\text { with the large } \\
\text { partner } \\
\text { company. }\end{array}$ \\
\hline
\end{tabular}




\section{Table A2}

Chronological matrix for evolution in the business model of the incubator studied

\begin{tabular}{|c|c|c|c|c|}
\hline $\begin{array}{l}\text { Elements of the } \\
\text { business model }\end{array}$ & Study period 1 & Study period 2 & Study period 3 & Study period 4 \\
\hline \multicolumn{5}{|l|}{$\begin{array}{l}\text { Content of the } \\
\text { activities of the } \\
\text { incubator }\end{array}$} \\
\hline $\begin{array}{l}\text { Activities } \\
\text { performed by the } \\
\text { incubator }\end{array}$ & $\begin{array}{l}\text { (1) Creating a } \\
\text { support program; } \\
\text { (2) Selecting the } \\
\text { entrepreneurs; } \\
\text { (3) Forming the } \\
\text { financial structure } \\
\text { of the incubator; } \\
\text { (4) } \\
\text { Communicating } \\
\text { with regard to the } \\
\text { incubator and the } \\
\text { businesses } \\
\text { supported; } \\
\text { (5) Carrying out } \\
\text { administrative } \\
\text { tasks. }\end{array}$ & $\begin{array}{l}\text { Stability of the } \\
\text { activities }\end{array}$ & $\begin{array}{l}\text { Developing the } \\
\text { services to } \\
\text { businesses } \\
\text { activity in the } \\
\text { context of } \\
\text { opening the } \\
\text { coworking } \\
\text { space. }\end{array}$ & $\begin{array}{l}\text { Developing an } \\
\text { activity for } \\
\text { designing } \\
\text { acceleration } \\
\text { programs in the } \\
\text { context of the } \\
\text { business } \\
\text { accelerator } \\
\text { project. }\end{array}$ \\
\hline \multicolumn{5}{|l|}{$\begin{array}{l}\text { Governance of } \\
\text { the activities of } \\
\text { the incubator }\end{array}$} \\
\hline $\begin{array}{l}\text { Role of the } \\
\text { employees of the } \\
\text { incubator in } \\
\text { implementing the } \\
\text { incubator's } \\
\text { business model }\end{array}$ & $\begin{array}{l}\text { (1) The manager } \\
\text { was responsible } \\
\text { for the strategic } \\
\text { and financial } \\
\text { aspects of the } \\
\text { incubator. He also } \\
\text { took part in } \\
\text { selecting the } \\
\text { entrepreneurs and } \\
\text { the support } \\
\text { program; } \\
\text { (2) The coaches } \\
\text { selected the } \\
\text { entrepreneurs, the } \\
\text { support program } \\
\text { and its piloting; }\end{array}$ & $\begin{array}{l}\text { Stability of the role } \\
\text { of the employees of } \\
\text { the incubator. }\end{array}$ & $\begin{array}{l}\text { The new } \\
\text { services to } \\
\text { businesses } \\
\text { activity was } \\
\text { performed by } \\
\text { the manager of } \\
\text { the incubator } \\
\text { and his } \\
\text { assistants. }\end{array}$ & $\begin{array}{l}\text { The new } \\
\text { activity of } \\
\text { defining the } \\
\text { acceleration } \\
\text { program will be } \\
\text { performed by } \\
\text { the manager of } \\
\text { the incubator. }\end{array}$ \\
\hline
\end{tabular}




\begin{tabular}{|c|c|c|c|c|}
\hline & $\begin{array}{l}\text { (3) The assistants } \\
\text { also piloted the } \\
\text { support and took } \\
\text { charge of } \\
\text { administrative } \\
\text { activities, as well } \\
\text { as communication } \\
\text { activities. }\end{array}$ & & & \\
\hline $\begin{array}{l}\text { Role of the } \\
\text { incubator's public } \\
\text { sector partners in } \\
\text { implementing the } \\
\text { incubator's } \\
\text { business model }\end{array}$ & $\begin{array}{l}\text { These partners } \\
\text { participated in the } \\
\text { following } \\
\text { activities: } \\
\text { (1) Selecting the } \\
\text { entrepreneurs and } \\
\text { (2) Carrying out } \\
\text { the support } \\
\text { program; } \\
\text { (3) They also } \\
\text { financed the } \\
\text { incubator and the } \\
\text { supported } \\
\text { entrepreneurs. }\end{array}$ & $\begin{array}{l}\text { Stability of the role } \\
\text { of the incubator's } \\
\text { public sector } \\
\text { partners. }\end{array}$ & $\begin{array}{l}\text { Stability of the } \\
\text { role of the } \\
\text { incubator's } \\
\text { public sector } \\
\text { partners. }\end{array}$ & $\begin{array}{l}\text { Stability of the } \\
\text { role of the } \\
\text { incubator's } \\
\text { public sector } \\
\text { partners. }\end{array}$ \\
\hline $\begin{array}{l}\text { Role of the } \\
\text { incubator's private } \\
\text { sector partners in } \\
\text { implementing the } \\
\text { incubator's } \\
\text { business model }\end{array}$ & $\begin{array}{l}\text { They performed } \\
\text { (1) consultancy } \\
\text { missions for the } \\
\text { entrepreneurs, and } \\
\text { (2) intervened } \\
\text { during the events } \\
\text { organized by the } \\
\text { incubator. }\end{array}$ & $\begin{array}{l}\text { Stability of the role } \\
\text { of the incubator's } \\
\text { private sector } \\
\text { partners. }\end{array}$ & $\begin{array}{l}\text { (1) Organizing } \\
\text { many events } \\
\text { within the } \\
\text { coworking } \\
\text { space; } \\
\text { (2) Developing a } \\
\text { partnership with } \\
\text { a large company } \\
\text { for a business } \\
\text { accelerator } \\
\text { project. }\end{array}$ & $\begin{array}{l}\text { Stability of the } \\
\text { role of the } \\
\text { incubator's } \\
\text { private sector } \\
\text { partners. }\end{array}$ \\
\hline \multicolumn{5}{|l|}{$\begin{array}{l}\text { Structure of the } \\
\text { incubator's } \\
\text { activities } \\
\end{array}$} \\
\hline $\begin{array}{l}\text { Nature of the } \\
\text { transactions with } \\
\text { the public sector } \\
\text { partners }\end{array}$ & $\begin{array}{l}\text { Partnership } \\
\text { relations were free } \\
\text { of charge and } \\
\text { informal }\end{array}$ & $\begin{array}{l}\text { Stability of the } \\
\text { nature of the } \\
\text { transactions with } \\
\text { the incubator's } \\
\text { public sector } \\
\text { partners. }\end{array}$ & $\begin{array}{l}\text { Stability of the } \\
\text { nature of the } \\
\text { transactions with } \\
\text { the incubator's } \\
\text { public sector } \\
\text { partners. }\end{array}$ & $\begin{array}{l}\text { Stability of the } \\
\text { nature of the } \\
\text { transactions } \\
\text { with the } \\
\text { incubator's } \\
\text { public sector }\end{array}$ \\
\hline
\end{tabular}




\begin{tabular}{|l|l|l|l|l|} 
& & & partners. \\
\hline & $\begin{array}{l}\text { (1) Relationships } \\
\text { with paid, } \\
\text { contractual ties } \\
\text { were developed } \\
\text { and defined in the } \\
\text { context of calls for } \\
\text { tender; } \\
\text { (2) Mutualization } \\
\text { of the services } \\
\text { provided by } \\
\text { private sector } \\
\text { partners was } \\
\text { transactions with } \\
\text { the private sector } \\
\text { partners }\end{array}$ & $\begin{array}{l}\text { Stability of the } \\
\text { nature of the } \\
\text { transactions with } \\
\text { the incubator's } \\
\text { private sector } \\
\text { partners. }\end{array}$ & $\begin{array}{l}\text { Relationship in } \\
\text { the process of } \\
\text { being formalized } \\
\text { with the large } \\
\text { company. } \\
\text { incubators to } \\
\text { reduce the costs of } \\
\text { the services. }\end{array}$ & $\begin{array}{l}\text { Relationship in } \\
\text { the process of } \\
\text { being } \\
\text { formalized with } \\
\text { the large } \\
\text { company. }\end{array}$ \\
\hline
\end{tabular}




\section{REFERENCES}

Aaboen, L. 2009. Explaining Incubators Using Firm Analogy. Technovation, 29:10, 657-70.

Achtenhagen, L., Melin, L., \& Naldi, L. 2013. Dynamics of Business Models - Strategizing, Critical Capabilities and Activities for Sustained Value Creation. Long Range Planning, 46: $6,427-442$.

Aernoudt, R. 2004. Incubators: Tool for Entrepreneurship?. Small Business Economics, 23:2, $127-135$.

Amit, R., \& Zott, C. 2001. Value Creation in E-Business Management. Strategic Management Journal, 22: 6/7, 493-520.

Arend, R. J. 2014. Entrepreneurship and Dynamic Capabilities: How Firm Age and Size Affect the 'Capability Enhancement-SME Performance' Relationship. Small Business Economics, 42:1, 33-57.

Bank, N., Fichter, K., \& Klofsten, M. 2017. Sustainability-profiled Incubators and Securing the in Flow of Tenants - The Case of Green Garage Berlin. Journal of Cleaner Production, 157: 76-83.

Baraldi, E., \& Ingemansson Havenvid, M. 2016. Identifying New Dimensions of Business Incubation: A Multi-Level Analysis of Karolinska Institute's Incubation System. Technovation, 50-51: 53-68.

Bergek, A., \& Charlotte N. 2008. Incubator Best Practice: A Framework. Technovation, 28: 1-2, 20-28.

Bruneel, J., Ratinho, T., Clarysse, B., \& Groen, A. 2012. The Evolution of Business Incubators: Comparing Demand and Supply of Business Incubation Services across Different Incubator Generations. Technovation, 32: 2, 110-121.

Clarysse, B., Wright, M. Lockett, A. Van de Velde, E., \& Vohora, A. 2005. Spinning out New Ventures: A Typology of Incubation Strategies from European Research Institutions. Journal of Business Venturing, 20: 2, 183-216.

Cohen, S. 2013. What Do Accelerators Do? Insights from Incubators and Angels. Innovations, 8: $3,19-25$.

Dahan, N. M., Doh, J. P., Oetzel, J., \& Michael Y. 2010. Corporate-NGO Collaboration: CoCreating New Business Models for Developing Markets”. Long Range Planning, 43: 2-3, 326-342. 
DaSilva, C. M., \& Trkman, P. 2014. Business Model: What It Is and What It Is Not. Long Range Planning, 47: 6, 379-389.

Demil, B., \& Lecocq, X. 2010. Business Model Evolution: In Search of Dynamic Consistency. Long Range Planning, 43: 2-3, 227-246.

Demil, B., Lecocq, X., Ricart, J. E., \& Zott, C. 2015. Introduction to the SEJ Special Issue on Business Models: Business Models within the Domain of Strategic Entrepreneurship. Strategic Entrepreneurship Journal, 9:1, 1-11.

Dutt, N., Hawn, O., Vidal, E., Chatterji, A., McGahan, A., \& Mitchell, W. 2016. How Open System Intermediaries Address Institutional Failures: The Case of Business Incubators in Emerging-Market Countries. Academy of Management Journal, 59:3, 818-840.

Economic commision for Europe. 2001. Best practice in business incubation, New York and Geneva: United Nations Press.

Eesley, C., \& Wang, Y. 2017. Social influence in career choice: Evidence from a randomized field experiment on entrepreneurial mentorship. Research Policy, 46: 3, 636-650.

Eisenhardt, K. M. 1991. Better Stories and Better Constructs: The Case for Rigor and Comparative Logic. Academy of Management Review, 16: 3, 620-627.

Eisenhardt, K. M., \& Graebner, M. E. 2007. Theory Building from Cases: Opportunities and Challenges. Academy of Management Journal, 50: 1, 25-32.

Eisenhardt, K. M.; Graebner, M. E. \& Sonenshein, S. 2016. From the Editors Grand Challenges and Inductive Methods : Rigor Without Rigor Mortis. Academy of Management Journal, 59: 4, 1113-1123.

Eisenhardt, K. M., \& Martin, J. A. 2000. Dynamic Capabilities: What Are They?. Strategic Management Journal, 21: 10-11, 1105-1121.

Foss, N. J., \& Saebi, T. 2017. Fifteen Years of Research on Business Model Innovation. Journal of Management, 43:1, 200-227.

Garrett, L. E., Spreitzer, G. M., \& Bacevice, P. A. 2017. Co-Constructing a Sense of Community at Work: The Emergence of Community in Coworking Spaces. Organization Studies, 38: 6, $821-842$.

George, G. \& Bock, A. J. 2011. The Business Model in Practice and Its Implications for Entrepreneurship Research. Entrepreneurship: Theory and Practice, 35:1, 83-111.

Hackett, S. M., \& Dilts, D. M. 2004a. A Systematic Review of Business Incubation Research. The Journal of Technology Transfer, 29: 1, 55-82. 
Hackett, S. M., \& Dilts, D. M. 2004b. A Real Options-Driven Theory of Business Incubation, Journal of Technology Transfer, 29: 1, 41-54.

Lamine, W., Mian, S., Fayolle, A., Wright, M., Klofsten, M., \& Etzkowitz, H. 2016. Technology business incubation mechanisms and sustainable regional development. Journal of Technology Transfer, Article in press: 1-21.

Messeghem, K., Carrier, C., Sammut, S., Thurik, R., \& Chabaud, D. 2013. L'accompagnement Entrepreneurial, Une Industrie En Quête de Leviers de Performance?. Management international, 17: 3, 65-71.

Miles, M. B., \& Huberman, M. A. 1994. Qualitative data analysis: An expanded sourcebook (2nd ed.). California : Sage editor.

Mian, S., Lamine, W., \& Fayolle, A. 2016. Technology Business Incubation: An Overview of the State of Knowledge. Technovation, 50-51: 1-12.

Morris, M., Schindehutte, M., \& Allen, J. (2005). The entrepreneur's business model: Toward a unified perspective. Journal of Business Research, 58: 6, 726-735.

Myers, M. D. 2013. Qualitative Research Business and Management, London: Sage editor.

Patton, D. 2014. Realising Potential: The Impact of Business Incubation on the Absorptive Capacity of New Technology-Based Firms. International small business journal, 32: 8, 897-917.

Pauwels, C., Clarysse, B., Wright, M., \& Van Hove, J. (2016). Understanding a New Generation Incubation Model: The Accelerator. Technovation, 50-51: 13-24.

Pezeshkan, A., Fainshmidt, S., Nair, A., Lance Frazier, M., \& Markowski, E. 2016. An empirical assessment of the dynamic capabilities-performance relationship. Journal of Business Research, 69: 8, 2950-2956.

Rice, M. P. 2002. Co-production of business assistance in business incubators An exploratory study. Journal of Business Venturing, 17: 2, 163-187.

Sosna, M., Trevinyo-Rodriguez, R. N. S., \& Ramakrishna V. 2010. Business Model Innovation through Trial-and-Error Learning: The Naturhouse Case. Long Range Planning, 43: 2-3, 383-407.

Somsuk, N., \& Laosirihongthong, T. 2014. A Fuzzy AHP to Prioritize Enabling Factors for Strategic Management of University Business Incubators: Resource-Based View. Technological Forecasting and Social Change, 85: 198-210.

Teece, D. J. 2014. A dynamic capabilities-based entrepreneurial theory of the multinational enterprise. Journal of International Business Studies, 45: 8-37. 
Teece, D. J. 2007. Explicating Dynamic Capabilities: The Nature and Microfoundations of (Sustainable) Enterprise Performance. Academy of Management Journal, 28: 1319-1350.

Teece, D. J. 2010. Business Models, Business Strategy and Innovation. Long Range Planning, 43:2-3, 172-194.

Teece, D. J; Pisano, G., Shuen, A. 1997. Dynamic Capabilities and Strategic Management. Strategic Management Journal, 18: 7, 509-533.

Vanderstraeten, J., \& Matthyssens, P. 2012. Service-Based Differentiation Strategies for Business Incubators: Exploring External and Internal Alignment. Technovation, 32: 12, 656-670.

van Weele, M., van Rijnsoever, F. J., \& Nauta, F. 2017. You Can't Always Get What You Want: How Entrepreneur's Perceived Resource Needs Affect the Incubator's Assertiveness. Technovation, 59: 18-33.

von Zedtwitz, M. 2003. Classification and management of incubators: aligning strategic objectives and competitive scope for new business facilitation. International Journal of Entrepreneurship and Innovation Management, 3: 1/2, 176-196.

Wu, H., Chen, J., \& Jiao, H. 2016. Dynamic Capabilities as a Mediator Linking International Diversification and Innovation Performance of Firms in an Emerging Economy. Journal of Business Research, 69: 8, 2678-2686.

Yin, R. K. 2013. Validity and Generalization in Future Case Study Evaluations. Evaluation, 19: 3, 321-332.

Zahra, S. A., Sapienza, H. J.; \& Davidsson, P. 2006. Entrepreneurship and Dynamic Capabilities: A Review, Model and Research Agenda, Journal of Management Studies, 43: 4, 917-955.

Zollo, M., Winter, S. G. 2002. Deliberate Learning and the Evolution of Dynamic Capabilities. Organisational Science, 13:3, 339-351.

Zott, C. 2003. Dynamic capabilities and the emergence of intraindustry differential firm performance: Insights from a simulation study. Strategic Management Journal, 24: 2, 97125.

Zott, C., \& Amit, R. 2007. Business Model Design and the Performance of Entrepreneurial Firms. Organization Science, 18: 2, 181-199.

Zott, C., \& Amit, R. 2008. The Fit Between Product Market Strategy and Business Model: Implications for Firm Performance. Strategic Management Journal, 29: 1-26.

Zott, C., \& Amit, R. 2010. Business Model Design: An Activity System Perspective. Long Range Planning, 43: 2-3, 216-226. 
Zott, C., Amit, R., \& Massa, L. 2011. The business model: Recent developments and future research. Journal of Management, 37: 4, 1019-1042. 